\title{
Regionalism as social capital for regional development. Competing views
}

\author{
Roman Szul \\ Centre for European Regional and Local Studies \\ University of Warsaw \\ U1. Krakowskie Przedmieście 30 \\ 00-927 Warsaw, Poland \\ r.szul@chello.pl
}

\begin{abstract}
In the $19^{\text {th }}$ and the first half of the $20^{\text {th }}$ century in Europe regionalism was considered by proponents of nation states as a backward movement which made building of modern states and modernisation processes difficult. In the post-war period in Western Europe some began to conceive the regionalism as a social capital encouraging for economic and social development and as a means for improving public governance. This concept was behind the administrative reform in Poland in 1999 when big quasi autonomous regions were established. In recent years, the economic crisis and political conflicts in some European countries strengthened scepticism about the role of regionalism.
\end{abstract}

Keywords: regionalism, Europe, EU, Poland, modernisation, governance, economic efficiency.

\section{Introduction}

In political studies the term "regionalism" has two different meanings - one that can be referred to as "sub-national regionalism" and is related to the regions understood as the parts of the existing nation states ${ }^{1}$ and the second ("supra-national regionalism") related to the regions as the parts of the world and consisting in an integration of the countries that belong to the same world region ${ }^{2}$. In the present paper this term in its former meaning is used. The idea of regionalism became popular several years ago (in the 1980s and 1990s) in Europe, especially in the European Union. It was believed that the regional identity and related social mobilisation of region's inhabitants together with improved governance due to greater autonomy of regional governments would contribute to an

${ }^{1}$ See for example the following definition of regionalism: Regionalism: The active promotion of regional interests in political, economic, social and cultural terms. Next, there are examples of regions provided, among others Catalonia, Basque Country, Galicia, Wales, Scotland, Flanders, Bavaria etc. Mathias 2006, 216-218.

${ }^{2}$ For this kind of understanding of the notion of regionalism, see e.g.: Research on regionalism was stimulated by the emergence in the late 1980s of the so-called new regionalism. Expansion and transformation of existing regional organizations such as the Association of South-east Asian Nations (ASEAN) and the European Union (EU) and the emergence of new regional groupings, for example, the Asia-Pacific Economic Cooperation (APEC) and the North American Free Trade Agreement (NAFTA) led to a reawakening of interest in regionalism and the construction of a new agenda in the study of regionalism. O’Brien, Williams 2007, p. 33. 
improved economic efficiency of public policies (economic growth) and to a better fulfilment of the inhabitants' needs. This opinion on regionalism was, among other things, behind the idea to carry out the administrative reform in Poland in 1999 and behind the attempts to revitalise or generate regionalism in Poland. Thus, the regionalism was perceived as social capital for development of regions and of the whole countries. At the same time there was an opposite opinion that the regionalism was a destructive force leading to political conflicts between regions and/or to irrational decisions of the regional authorities. The aim of this paper is to present competing views on regionalism over the last two hundred years, especially in Europe. The paper was inspired by the recent developments in the regionalist movements, for instance in the UK and Spain (Scottish and Catalan independence tendencies) which have revealed features of regionalism considered by some rather destructive than contributing to building of social capital for development and contradictory to the previous conviction that regionalism can be the only driving force of development. The author hopes that this paper which presents the origins and evolution of as well as the changing attitudes to regionalism would contribute to a better understanding of this important phenomenon.

\section{Nation building, modernisation and regionalism}

In $19^{\text {th }}$ and early $20^{\text {th }}$ century (more or less until the second world war) among the main ideas (or ideologies) driving for social change there were the ideas of nation-building (or nationalism) and modernisation. There were two kinds of nationalism: state nationalism and ethnic nationalism (or stateless nationalism).

The former aimed at transforming the inhabitants of the existing states into citizens and one nation according to the rule of "one state, one nation, one culture/language". This kind of nationalism was associated with modernisation ${ }^{3}$ understood as 1) centralisation of the state political power (nationstate), 2) its unification implying removal of obstacles to a free movement of goods, capital and people within national boundaries and elimination of all territorial inequalities in terms of rights and duties of citizens, 3) upgrading the level of education by introduction of a compulsory and free elementary education, as well as 4) technical or material modernisation (building technical infrastructures, especially nation-wide railway network, governmental incentives or direct involvement of national governments in development of industry with special reference to military industry). Nationalism and modernisation were conceived as two facets of the same phenomenon: nation as a precondition for modernisation, modernisation as an instrument strengthening the nation in its competition with other nations (for "territory and glory"). Nationalism and modernisation were "urban-biased": cities/towns were vehicles of spreading both the national idea and the modern lifestyle; these were places, especially the capital cities, where the driving forces (institutions, individuals) of nationalism and modernisation were located.

For this kind of nationalism and modernisation, a regionalism safeguarding regional (territorial) specificities in politics (regional political autonomy, special rights for some territories often stemming from feudal times), culture (safeguarding of regional customs, languages, identity etc.) and economy (promoting regional interests) was regarded as an anti-national and backward force. The only acceptable and even encouraged kind of regionalism was that referred to as "nation-building integrative regionalism" or "folkloristic regionalism". This kind of regionalism, accepted or even encouraged by

\footnotetext{
${ }_{3}^{3}$ Probably the best known scholar presenting nationalism as a modernisation ideology is Ernest Gellner, Gellner 2006.
} 
(all-national) political forces external to the concerned region, was limited to the cultural sphere only and consisted in demonstrating regional folklore (songs, dances, dress, oral culture in local dialects, etc.) and everyday life of region's population as integral elements of the nation concerned. The aim of this kind of regionalism was to present it as an element of the richness of the national culture (while competing with other nations $)^{4}$ and, if needed, as a first step of integrating region's population into the nation (waking up awareness of belonging to a region as the first step of integrating this population with the nation when and where the gap between characteristics of the given population and the "national norm" was too large to be overcome "by one leap" and intermediary steps were needed).

The folkloristic regionalism served modernisation in that it helped local (usually peasant) population integrate with the nation and neutralised its opposition to the nation-building process which was considered as being also modernisation process.

The above described relationship between nationalism, modernisation and regionalism was typical for West European countries, France being the most outstanding example. Also the states (nation states) in central-eastern Europe which emerged after the First World War followed suit: they also tried to build centralized nation states, "nationalise" their populations, in some instances making concessions to folkloristic regionalism ${ }^{5}$.

In certain countries the nationalism-modernisation idea (and policy) implying centralisation of the state and unification of its population clashed with decentralist tendencies which were striving to preserve regional specificities and privileges and were strong enough to challenge the unification efforts. In Western Europe it was the case of Spain in the first place. It can be said that the whole history of Spain in the $19^{\text {th }}$ century and much of the $20^{\text {th }}$ century was dominated by the conflict between the centripetal (all-Spanish nationalism) and centrifugal (particular regionalisms) forces ${ }^{6}$. The civil war of 1936-39 was also a part of this conflict since the revolt of General Franco was a reaction to granting autonomy to some regions by the republican government that he and his followers considered detrimental for national unity.

Not always nationalism was combined with the idea of modernisation. As mentioned above, besides the state nationalism there existed stateless or ethnic nationalism aimed mainly at preserving or promoting cultural identity of ethnic groups considered by their leaders as "nations" within the existing states, and at gaining a kind of autonomy or independence for these groups ${ }^{7}$. Modernisation, although not excluded as political objective, was secondary to identity and political goal. This kind of nationalism opposed the unification efforts by state nationalism and resembles cultural and political ethno-regionalism with the only difference between the two which consisted in the intensity of sentiments. Stateless (ethnic) nationalism was frequent in Central and Eastern Europe (in the Habsburg, Russian, Ottoman empires, to a lesser extent in Prussia/Germany), but it was not absent in Western Europe (for instance the Catalan or Basque movements revealed characteristics of ethnic nationalism). In some instances, as in the case of the Czech national movement in the Habsburg empire, Polish national movement in Prussia/Germany (in Poznań/Posen region) and in the Habsburg empire etc., the nationalism was a social force for modernisation: improving the economic position of one ethnic group, its cultural and educational level, etc. was instrumental in competition with the main ruling

\footnotetext{
${ }^{4}$ Fine more on folkloristic regionalism in Thiessová 2007 p.143-148. However, she takes into account only one type of folkloristic regionalism - that intended to demonstrate richness of the national culture, without analysing another aim existing in central-eastern Europe, namely gradual incorporation of a local population into the desired nation (and not the rival one) through the stage of regionalism.

5 For regionalism as the first step towards integration with a national community see Szul 2012.

${ }^{6}$ Cf: Olábarri Gortázar 1985.

7 On this kind of nationalism see e.g. Smith 2009.
} 
ethnic group in the state. The ethnic nationalism also had its regionalist component sometimes. The aim of such regionalism was to prepare population living in a certain area and presenting certain ethnic characteristics, and thus considered as potential members of the nation concerned, to join this nation and to prevent this population from joining a rival nation. For instance, this is the case of Kashubian or Silesian regionalism in the $19^{\text {th }}$ and early $20^{\text {th }}$ century Polish national movement in Prussia/Germany. (It should be mentioned that apart from this type of pro-Polish Kashubian regionalism there also existed Kashubian nationalism declaring Kashubians to be a separate ethnic nation rather than a part of the Polish ethnic nation). This kind of regionalism was not related directly to the idea of modernisation. If the modernisation meant abandoning the ethnic language, culture, identity, this kind of regionalism was anti-modernist.

To conclude it can be said that in the era of nationalism in the $19^{\text {th }}$ and the first half of the $20^{\text {th }}$ century, regionalism was largely considered as a backward force opposing nation-building identified with modernisation, or as a temporary instrument to introduce local populations into the (desired) nation. Whether this instrumental regionalism implied or not elements of modernisation depended on circumstances.

\section{"Europe of Regions", regionalism and modernisation}

The mainstream attitude towards regionalism in Western Europe started to change after the Second World War and accelerated in the 1980s with its culmination in the form of the idea of "Europe of Regions". According to this new opinion regionalism (regional identity) was favourable for better governance, strengthening of democracy and for international cooperation and European integration.

On the one hand, the new tendency was manifested by decentralisation processes including establishment of regional level of government provided with the competencies and even an autonomy in certain countries, but on the other hand, by the activities of grass-root movements whose aims ranged from preserving local/regional cultures, languages, historical and natural monuments, diffusing the knowledge on region's history and culture, etc., to demands of political and economic autonomy for a region or for all regions in a country.

Of great importance were the developments in Spain. After the death of general Franco in 1975 Spain entered a process of democratisation and decentralisation (regionalisation). Regionalist sentiments and movements suppressed during the Franco regime came to the fore. As a result Spain was gradually transforming into what is called "regional state” or ,estado de las autonomías", a form of state organisation with a high autonomy of regions although without declaring Spain a federation ${ }^{8}$. Autonomy of Spanish regions is asymmetrical in that the individual regions differ in terms of autonomy degree in the areas where regions express their identity and in forms of relations with the central government. Of special importance is the fact that some economically most developed regions, first of all Catalonia and the Basque Country, gained high level of political, economic and cultural autonomy (including recognition of the regional languages - Catalan and Basque - as coofficial languages in their respective regions, and efforts to strengthen their position in the society). Regionalisation of Spain was accompanied by the fast growth of Spanish economy, living standards and modernisation. The regions with the highest degree of autonomy belonged to those which were

\footnotetext{
8 More on the transformation of Spain into estado de las autonomias see: Linz 1985.
} 
developing the most rapidly. Successes of Spain and its regions in the 1980s and 1990s were largely attributed to the regionalisation, mobilisation of social capital by regionalist movements and regional governments.

Spanish experience exerted influence on some other countries, first of all on Italy which attempted to follow suit and to transform it into a "regional state"9. Successes of Spanish regions like Catalonia and the Basque country encouraged other regionalist movements in Western Europe ${ }^{10}$. These successes were interpreted as evidence that the regional autonomy, preservation and promotion of regional culture and identity and introduction of regional language into the public sphere, contrary to what nationalists-modernists used to recon, was not disadvantageous for the economic development and modernisation. Even more so, preservation and promotion of regional identity were interpreted as the capital mobilising society for harder work, better governance, etc. Apart from Spain and Italy, a process of decentralisation called "devolution" has been taking place in the United Kingdom since the late 1990s with greater autonomy for Scotland and Wales (as well as for Northern Ireland as a solution for the conflict between the two communities - Protestants/loyalists and Catholics/republicans). The process of decentralisation and regionalisation took place even in France, the most centralistic state in Western Europe. There were established regions as administrative territorial units and cultural regionalism promoting regional culture and languages (e.g. in schools as a subject or language of instruction) was accepted, although unlike Spain, UK, Italy or the Netherlands, no regional language in France was allowed to be co-official language in any region or province. After the Second World War also West Germany underwent a process of decentralisation in the form of federalisation. It was, however, not a grass-root movement, but was imposed by the occupying powers as a remedy for the German nationalism and Nazism ${ }^{11}$.

The new favourable attitude towards regionalism in Western Europe after the Second World War can be attributed to several factors. Probably one of the most important was the "mental revolution" caused by the shock of the two world wars and the related revision of the idea of nationalism which was accused of being the driving force of hostilities and wars between European nations. Downgrading nationalism as a social and political idea gave more room both to cooperation between nations leading to European integration, and to regionalism. Along with the revision of nationalism, the traditional idea of modernity and modernisation was also revised giving way to the so called "post-" or "late modernity". In the concept of post-modernity the idea of "diversity" gained importance. "Diversity", be it biological or cultural, became a positive value that should be protected and promoted. Regionalism, at least cultural regionalism, inscribed itself into the notion of diversity. The positive valuation of regionalism created favourable atmosphere for those who wanted to engage in rescuing and demonstrating regional cultures, languages, etc. It is worth mentioning that quite often persons active in cultural regionalism are not those born in the respective regions or born to families stemming from these regions. They spend their energy, time, and sometimes money to save a regional language or cultural heritage in the name of safeguarding an element of human heritage and diversity.

Almost complete victory of the unification-modernisation forces was another reason for the positive atmosphere for regionalism. After a period of forced unification and homogenisation of West

9 It is interesting to note that Italy uses the same terminology as Spain: stato regionale, stato delle autonomie or reppublica delle autonomie (equivalent to Sanish estado regional, estado de las autonomies. For Italian reppubica delle autonomie see: Misiuda-Rewera 2005.

${ }^{10}$ For the post-war regionalism in Europe see more in: Mathias, op. cit.

11 See Swenden 2006. 
European states there had remained few instances of regions (regional communities) strong enough and willing enough to challenge territorial integrity of the existing states. In such a situation governments and societies could afford to be generous for struggling regional cultures, languages, customs, and their defenders. This attitude was an element of the then popular idea of multiculturalism.

Of special importance was international cooperation and European integration. One of results of this was the trust between (West) European states (nations) and the lack of threat that a neighbouring state or another power would take advantage of a regionalist movement in our country to destabilise it. This opened up the way not only to activities of regionalist movements within national boundaries but also to cross-border cooperation.

European cooperation and integration not only created favourable atmosphere for regionalism. Institutions of European integration - the Council of Europe and the European Union (including its previous forms) have created legal and institutional framework and material incentives for regionalism. The European Charter of Regional Self-Government adopted by the Council of Europe in 1997 (drafted by the Council's Congress of Local and Regional Authorities of Europe (CLRAE) with the support of the Committee of the Regions of the European Union) and the European Charter for Regional or Minority Languages adopted by the Council of Europe in 1992 represent elements of the legal framework supporting various kinds of regionalism. The EU Committee of the Regions can be regarded as a contribution of the EU to creation of the institutional framework of regionalism.

As regards the material contribution of the European Union to the broadly conceived regionalism and regionalisation, the EU's regional policy should be mentioned. The EU provides considerable resources for regional development which are channelled through regional authorities. Besides, one of principles of the EU regional and cohesion policy requires participation of regional authorities in drafting and implementing development programmes financed by the EU. It is assumed that the participation of regional authorities ensues efficient use of development funds. This requirement has been incentive for beneficiaries of EU funds to create regions as territorial units dealing with EU funds.

According to a wide-spread opinion, there was a symbiosis between regionalism and European integration ${ }^{12}$ : regionalism (regionalisation of nation states) softened conflicts between the states and thus opened up broader space for international cooperation and integration, the integration, as mentioned earlier, reduced tension between states and made them less vulnerable to possible centrifugal tendencies in their respective regions. It was assumed that regional (as well as local) authorities were preoccupied only with pragmatic issues of serving everyday needs of their inhabitants and with efficient use of resources unlike national government which were more inclined towards conflicting ambitions. This idea was expressed, as mentioned earlier, in the popular notion of the "Europe of Regions".

When central-eastern European countries, after the end of the cold war, decided to join the European Union, regionalism and regionalisation were regarded as something closely linked to European integration, democratisation and economic progress, at least to efficient use of European funds.

This opinion on regionalisation and regionalism was best reflected in the administrative-territorial reform of Poland which came into force in 1999. This reform abolished the previous two-tier administrative-territorial system ("small" 49 voivodships being only territorial units of central administration, and communes with elected local governments and councils) and introduced a

12 On this (real or imagined) symbiosis see Biscoe 2001. 
tree-level system ("big" 16 voivodships - poviats - communes). What is interesting is that the "big" voivodships also called regiony (regions). They were given some degree of autonomy (selfgovernance), regional parliaments elected in regional elections, and regional governments elected by regional parliament. The aim of establishing the regions (voivodships) was twofold: to facilitate access to and utilisation of the EU funds for regional development, and to provide a driving force for economic development and modernisation by mobilisation of the social capital in the region. It was believed, at least by those who promoted the reform, that the regions would arouse or create regional identity, regional pride mobilising for harder work, better governance etc. ${ }^{13}$. It is interesting to note that in order to generate regional identity and pride the new regions were given "historical" names, despite the tradition that territorial units have names derived from names of their main cities. These "historical" names referred to historical regions from various periods of Poland's history or were recently invented.

\section{Regionalism as a destructive force}

Not all observers of regionalism in recent decades are positive about it. Its critics point out to different negative characteristics of regionalist movements, depending on place and time. There are three main reasons for critical attitude towards regionalism: 1) regional economic selfishness, mostly for rich regions, 2) threat for political unity of the states, and for social and political cohesion of the regions concerned when regionalist movements grow into nationalism and separatism, 3) wasteful ambitions of regional authorities.

Activity of certain regionalist movements in rich regions, especially in the 1990s and later, like Lega Nord (also known as "Padania") in Italy, Catalonia in Spain, Slovenia and Croatia in the former Yugoslavia, which demand reductions of financial transfers (or their total elimination) from these regions to less fortunate regions of their states is the evidence of economic selfishness of these regions for certain observers. The argument which is often raised by these regions that their wealth results from their hard work, thrift, etc. stretches the truth according to its critics: this wealth is often an effect of incidental geographical and historical factors or past decisions of national authorities and has been possible due to the access to the all-national market and to the inflow of cheap labour force from other regions. In such a situation interruption of financial flows from richer regions to the central government and poorer regions is not restoring "interregional justice" but is an act of economic selfishness detrimental for smooth, efficient functioning of national economy and for the very unity of the national states ${ }^{14}$.

There is no clear-cut distinction between regionalism and nationalism/separatism. A regional movement (or its radical representatives) aiming at defending this region's identity and political and economic interests may conclude that it is possible, only provided that the region has gained political independence or a special autonomy above limits consented by the state. This has happened in Spain (separatist tendencies in Catalonia and the Basque Country) and in the UK (Scotland). In Catalonia in

13 The belief in regionalism as a social capital for modernisation is presented e.g. in Szomburg (ed.) 2009, especially in Sagan 2009.

14 Such opinion on regionalism can be found, for instance, in Gauß (2008) p. 143. Austrian writer and philosopher Markus Gauß in his book "European alphabet" dedicates one part to regionalism. His opinion on regionalism is strongly negative, he does not find anything positive in it, it is, for him, a pure selfishness a kind of new racism (based not on physical characteristics of people but on their "intimate organs - the wallets"). 
Autumn 2012 its prime minister Artur Mas warned that his government would organise referendum on Catalonia's independence even though it would be illegal (according to the Spanish constitution such a referendum would require consent of the central authorities). In the Basque Country the idea of a special status for this region ("free association" of the Basque Country with Spain) has been frequently raised by the regional Basque government which, however, did not dare to organise a referendum on this despite declarations that it intended to do so. In Scotland, after negotiations between the Scottish regional government and the central government in London, referendum on Scotland's independence was due to be held in September 2014. (Scottish voters rejected the idea of independence by a majority of 55:45; it should be noted, however, that before the referendum British prime minister promised to increase Scotland's autonomy to convince Scots to reject independence, which means that the process of the change of the construction of the UK is not finished.) Such tendencies provoke negative reactions not only in countries concerned, especially in Spain where its government and a large part of the society is afraid of repeating the experience of Yugoslavia in the $1990 \mathrm{~s}^{15}$, but also in the European Union which warns that the new states would not be admitted to the EU automatically ${ }^{16}$. It also should be noted that the idea of a region's independence is conflicting for the region itself.

Defence and promotion of regional cultural identity, particularly language, is a particular problem. Official recognition of a language and even making it co-official language in the relevant region needs not to provoke any negative reactions by its inhabitants as long as they have the choice between the two languages (the all-national and the regional one). The rebirth of regional languages in Europe in recent decades gave such a choice even though in some situations dealing with both languages was compulsory (e.g. in schools). In other situations the use of one of the two languages was optional. Given that the region is not isolated from the rest of the country (state) and its inhabitants must maintain contacts with the all-national language, it implies that users of a regional language have to be bilingual. After several years of the official policy of rebirth and promotion of regional languages it turned out that such a policy had its limits: while these languages advanced in the public sphere they continued to be pushed out from the private sphere as living languages and that retention of active bilingualism was difficult. In such a situation some defenders of regional languages, especially in Catalonia and the Basque Country, realised that the free choice of languages always preferred the stronger language - the all-national one, and if the regional language is really to be preserved and used in all spheres, the access to the all-national language should be limited. According to this opinion school education was crucial in this respect: school children had to learn and be taught mostly (if not exclusively) in the regional language to make them speak and think in this language. Attempts of introducing such a policy in Catalonia and the Basque Country, apart from provoking negative reactions in other regions of Spain and protests of the central authorities, were also opposed by a large number of inhabitants of these regions, especially by the parents who were afraid that without the knowledge (or a good knowledge) of Spanish their children would be handicapped in the Spanish (and Spanish-speaking countries) labour market. Controversies are not limited to the school education. They are also aroused, among other things, by the fines levied in

15 E.g. see the title of a book which can serve as a political manifesto: Contra la balcanización de España (Moa Rodríguez 2005), see also: Mir y Cruz 2012.

$16 \mathrm{Cf}$ : Mr Mas is also accused of adventurism in pretending that Catalonia can unilaterally become an independent state in the EU. According to several opinions of the European Commission an independent Catalonia would not automatically become a member of the EU and Spain would have to approve its (re)admission, Briefing Spain and Catalonia. The trials of keeping a country together, "The Economist" November 24th 2012, p. 26. The same attitude of the EU concerned Scotland. 
Catalonia from businesses for Spanish names of local firms. Conflicts concerning the language policies of regional governments of these two (and some other) regions add to the general conflict concerning the position of regions in the Spanish state. They also indicate that the attitude towards regionalism is far from unanimous support. Institutions of the European integration - the EU and the Council of Europe, although officially neutral in matters of language policy of its Member States (in the case of the EU) or favourable for regional languages (the Council of Europe) seem to consider that regionalist movements have crossed some acceptable limits in their promotion of regional languages. Their attitude towards EBLUL (European Bureau for Lesser Used Languages) unreservedly supporting such policies may be a symbol of their approach towards regional language policies. In the past EBLUL was considered NGO associated with the EU and the Council of Europe and enjoying their political and financial support. In 2009, EBLUL was deprived of the funds and ceased to exist.

Another strain of criticism of regionalism in recent years relates to its contribution to economic problems, first of all public debt and low economic competitiveness of south European countries. In Spain, affected by the high public debt, very high unemployment rate, especially among the young, and necessity to cut spending in the framework of austerity policy, attention was turned to regions as sources of the debt and insufficient competitiveness of the economy. This is justified by the significant role of regional government in public spending (more than one half) and in running the economy in general. The critics of the regions found a lot of examples of irrational decisions motivated by political ambitions of regional governments and their leaders, corruption, bad management etc. ${ }^{17}$. Regional identity policy has been also criticized as a source of irrationality and low economic efficiency, regional language policies being again at the heart of the controversy ${ }^{18}$.

It is interesting to note that the austerity policy imposed on Spain by the EU actually forced Spanish government to reduce the economic autonomy of Spanish regions. According to unofficial statements of EU functionaries the economic autonomy of Spanish regions is exaggerated and should be curtailed. Thus, the European Union, once thought to be ally of regions and regionalism, has turned out to be adversary of (some forms of) regionalism.

\section{Conclusions}

Over the last two hundred years the attitudes towards regionalism in Europe have changed. In the $19^{\text {th }}$ and the first half of the $20^{\text {th }}$ century, in the time of building nation states, regionalism was regarded by those who were not directly engaged in regionalist movements as a backward force hindering building of modern nation states identified with modernisation and progress. After the Second World War the criticism of nationalism as a force driving for intolerance, conflicts and wars opened the way

17 See, for example, a long list of „sins” of regional governments in Spain in: Mir y Cruz 2012.

18 For instance Mir and Cruz in the above quoted book point out to wasting of money (in their opinion) for programmes of promotion of regional languages and to problems caused to entrepreneurs and employees by such a policy. Among other things they mention a business club in Vigo (Galicia) (Club Financiero de Vigo) which complains that despite the high unemployment in Spain and in the region employers in Vigo can not attract highly qualified employees from other regions of Spain neither retain their own employees in Vigo because the school education is only in Galician: employees don't want to live here and send their children to local Galician-language schools considered as worse than Spanish-language ones (Mir Cruz G 2012 p. 254). Author of this paper checked the webpage of Vigo municipality and found that despite of being theoretically bilingual (Galician and Spanish/Castilian, with Galician as the default language) most information in the nominally Castilian-language version was in fact in Galician, without translation. . http://hoxe.vigo.org (access: November 29, 2013). 
to several phenomena known as "post-modernity" with its central element of "diversity" as well as to European integration in the western part of the continent. In these new circumstances the regionalism was regarded as a positive idea supporting cultural diversity, deepening democracy and demobilising nationalist sentiments and thus contributing to peace, international cooperation and European integration. Besides, it was believed that giving more power to regions would enhance efficiency of public policies. In such an atmosphere a popular idea of the "Europe of regions" emerged. Regionalism and regionalisation were also supported by the European Union within the framework of its regional policy. The Central-Eastern European countries which acceded to the EU in 2004, especially Poland, made attempts to create or revitalise regionalism believing that this would, first, facilitate access to, and utilisation of, European funds, and, second, to raise social capital mobilising for modernisation of the country. In recent years some expressions of regionalism have turned attention of observers to its drawbacks such as regional selfishness detrimental to social peace and to radical forms of regionalism jeopardising political unity of some countries. Besides, it has turned out that regional governments are not immune to what some observers consider as bad governance.

\section{References}

Biscoe A., 2001. European Integration and the Maintenance of Regional Cultural Diversity: Symbiosis or Symbolism? Regional Studies, Journal of the Regional Studies Association, vol. 35, no. 1, February 2001 pp. 57-64.

Briefing Spain and Catalonia. The trials of keeping a country together. "The Economist" November $24^{\text {th }} 2012,26 \mathrm{pp}$.

Gauß K.-M., 2008. Europejski alphabet. (from German translated by Alicja Rosenau) Wołowiec: Wydawnictwo Czarne (German original: Das europäische Alphabet, Wien: Paul Zsolnay Verlag, 1997), $161 \mathrm{pp}$.

Gellner E. 2006. Nations and Nationalism. $2^{\text {nd }}$ edition. Malden-Oxford-Carlton: Blackwell, 152 pp. Misiuda-Rewera W., 2005. Włochy. Republika autonomii. Lublin: Wydawnictwo UMCS, 239 pp.

Linz J. J., 1985. De la crisis de un estado unitario al estado de las autonomías. [in:] F. Fernández Rodríguez (ed.), La España de las autonomías, Madrid: Instituto de Eastudios de Administración Local, pp. 527-672.

Mathias J., 2006. Regions and Regional Politics in Europe. [in:] R. Sakwa and A. Stevens (eds.), Contemporary Europe, Second edition, Basingstoke: Palgrave Macmillan, pp. 213-232.

Mir S., Cruz G., 2012. La Casta Autonómica. Madrid: La Esfera de los Libros, 334.

Moa Rodríguez L. P., 2005. Contra la balcanización de España. Madrid: La esfera de los libros, 217 pp.

O’Brien R., Williams M., 2007. Global Political Economy. Evolution and Dynamics, 2nd edition. Basingstoke: Palgrave Macmillan, 473 pp.

Olábarri Gortázar I., 1985. Un conflicto entre nacionalismos: la „cuestión regional” en España 1808-1939. [in:] F. Fernández Rodríguez (ed.), La España de las autonomías, Madrid: Instituto de Estudios de Administración Local, pp. 69-168.

Sagan I., 2009. Czym sq i jak funkcjonuja dzisiejsze regiony Polski. [in:] J. Szomburg (ed.) Jak uczynić regiony motorami rozwoju i modernizacji Polski, Gdańsk: Polskie Forum Obywatelskie and Instytut Badań nad Gospodarką Rynkową, pp. 27-34. 
Smith A. D., 2009. Ethno-Symbolism and Nationalism. A cultural approach. Oxon-New York: Routledge, $184 \mathrm{pp}$.

Swenden W., 2006. Federalism and Regionalism in Western Europe. A Comparative and Thematic Analysis. Basingstoke: PalgraveMacMillan, 325 pp.

Szomburg J. (ed.) 2009. Jak uczynić regiony motorami rozwoju i modernizacji Polski. Gdańsk: Polskie Forum Obywatelskie and Instytut Badań nad Gospodarką Rynkową, 140 pp.

Szul R., 2012. Regionalizm. Refleksje na temat ewolucji idei i praktyki regionalizmu w Europie. [in:] A. Pawłowska, Z. Rykiel (eds.), Region i regionalizm w socjologii i politologii, Rzeszów: Wydawnictwo Uniwersytetu Rzeszowskiego, pp. 31-46.

Thiessová A.-M., 2007. Vytvárení národnich identitet v Evropě 18. až 20 století. Brno: Centrum pro studium demokracie a kultury (Translation from French: Anne-Marie Thiesse Création des identités nationales, Éditions du Seuil 1999), 263 pp. 
http://rcin.org.pl 